\title{
CD69 downregulates autoimmune reactivity through active transforming growth factor $\beta$ production in collagen-induced arthritis
}

\author{
David Sancho, ${ }^{1}$ Manuel Gómez, ${ }^{1}$ Fernando Viedma, ${ }^{1}$ Enric Esplugues, ${ }^{2}$ \\ Mónica Gordón-Alonso, ${ }^{1}$ María Angeles García-López, ${ }^{1}$ Hortensia de la Fuente, ${ }^{1}$ \\ Carlos Martínez-A, ${ }^{3}$ Pilar Lauzurica, ${ }^{2}$ and Francisco Sánchez-Madrid ${ }^{1}$ \\ ${ }^{1}$ Servicio de Inmunología, Hospital de la Princesa, Universidad Autónoma de Madrid, Madrid, Spain \\ ${ }^{2}$ Departamento de Fisiología, Universidad de Barcelona, Barcelona, Spain \\ ${ }^{3}$ Department of Immunology and Oncology, Centro Nacional de Biotecnología, Centro Superior de Investigaciones \\ Científicas-Universidad Autónoma de Madrid, Madrid, Spain
}

\begin{abstract}
CD69 is induced after activation of leukocytes at inflammatory sites, but its physiological role during inflammation remains unknown. We explored the role of CD69 in autoimmune reactivity by analyzing a model of collagen-induced arthritis (CIA) in WT and CD69-deficient mice. CD69-/- mice showed higher incidence and severity of CIA, with exacerbated $\mathrm{T}$ and $\mathrm{B}$ cell immune responses to type II collagen. Levels of TGF- $\beta 1$ and TGF- $\beta 2$, which act as protective agents in CIA, were reduced in $\mathrm{CD} 69^{-/-}$mice inflammatory foci, correlating with the increase in the proinflammatory cytokines IL-1 $\beta$ and RANTES. Local injection of blocking anti-TGF- $\beta$ antibodies increased CIA severity and proinflammatory cytokine mRNA levels in $\mathrm{CD} 69^{+/+}$but not in $\mathrm{CD}^{-/-}$mice. Moreover, in vitro engagement of CD69 induced total and active TGF- $\beta 1$ production in Concanavalin A-activated splenocyte subsets, mouse and human synovial leukocytes, and Jurkat stable transfectants of human CD69 but not in the parental CD69 negative cell line. Our results show that CD69 is a negative modulator of autoimmune reactivity and inflammation through the synthesis of TGF- $\beta$, a cytokine that in turn downregulates the production of various proinflammatory mediators.
\end{abstract}

J. Clin. Invest. 112:872-882 (2003). doi:10.1172/JCI200319112.

\section{Introduction}

CD69 is a leukocyte receptor transiently induced after activation (1-5) that is detected on small subsets of $\mathrm{T}$ and $\mathrm{B}$ cells in peripheral lymphoid tissues from healthy subjects (6). In addition, CD69 is persistently expressed in leukocyte infiltrates of various chronic inflammatory diseases $(7,8)$. Several reports have indicated that CD69 is involved in the in vitro activation of bone marrow-derived cells $(2,3,9)$. Nevertheless, the functional role of this molecule could be different in vivo. Transgenic $\mathrm{CD} 69$ mice accumulate mature thymocytes at the medulla of the thymus $(10,11)$. In this regard, we have found that hematopoietic cell development, thymocyte positive and negative selection, and $\mathrm{T}$ cell maturation is normal in $\mathrm{CD} 69^{-/-}$mice under physiological condi-

Received for publication June 4, 2003, and accepted in revised form July 8, 2003

Address correspondence to: Francisco Sánchez-Madrid, Servicio de Inmunología, Hospital de La Princesa, C/ Diego de León 62, E-28006 Madrid, Spain. Phone: 34-91-5202370;

Fax: 34-91-5202374; E-mail: fsanchez.hlpr@salud.madrid.org.

Conflict of interest: The authors have declared that no conflict of interest exists.

Nonstandard abbreviations used: collagen-induced arthritis (CIA); type II collagen (CII); rheumatoid arthritis (RA); [methyl- $\left.{ }^{3} \mathrm{H}\right]$ thymidine $\left(\left[{ }^{3} \mathrm{H}\right] \mathrm{TdR}\right)$ Concanavalin $\mathrm{A}(\mathrm{ConA})$; macrophage inflammatory protein (MIP); Jurkat T cells stably transfected with human CD69 (JK-CD69); cytoxic

T-lymphocyte-associated antigen-4 (CTLA-4). tions (12). In addition, NK cell-dependent tumor rejection is favored in the absence of CD69 (13). However, the functional role of CD69 expressed by T cells and macrophages at inflammatory sites and in autoimmune processes has not been explored.

Murine collagen-induced arthritis (CIA) is a T cell-dependent, antibody-mediated autoimmune disease directed against cartilage type II collagen (CII) (14). CIA is a widely accepted experimental model of inflammatory joint disease, mainly rheumatoid arthritis (RA) (14). A strong inflammatory cell infiltrate with proliferation of synovial cell lining (pannus) as well as cartilage and bone destruction are seen in CIA and RA. In addition, proinflammatory cytokines (IL- $1 \beta$, TNF- $\alpha$ ) and various chemokines are involved in the pathogenesis of the immune-mediated joint damage observed in CIA and RA (15). TGF- $\beta 1$ is considered an anti-inflammatory cytokine, and null mutations of the TGF- $\beta 1$ gene result in a severe multiorgan inflammatory disorder that is rapidly lethal $(16,17)$. TGF- $\beta 1$ downregulates proinflammatory cytokine production $(18,19)$ and exerts a clear-cut protective effect on CIA $(20,21)$. However, intra-articular injection of high amounts of this cytokine also induces synovitis and fibroblast hyperplasia (22), and systemic administration may be deleterious (23). The balance between proinflammatory and anti-inflammatory cytokines is thus crucial to the outcome of the disease (15). Therefore, tissue levels 
of TGF- $\beta$ have a critical role in inflammation, and the molecules involved in its modulation are interesting potential therapeutic targets.

To ascertain the functional in vivo role of CD69 in autoimmune reactivity and inflammation, we analyzed the behavior of CIA in CD69-deficient B6 mice. An exacerbated form of CIA was observed in $\mathrm{CD} 69^{-/-}$mice that correlated with higher CII-specific $\mathrm{T}$ and $\mathrm{B}$ cell responses, an increase in some inflammatory mediators, and diminished local TGF- $\beta$ synthesis. Local blockade of TGF- $\beta$ increased CIA severity in WT but not in CD69deficient mice. In addition, in vitro engagement of CD69 induced the production of TGF- $\beta 1$. These results strongly suggest that CD69 is a negative regulator of autoimmune reactivity through TGF- $\beta$ synthesis.

\section{Methods}

Mice. Mice were bred at the Centro Nacional de Biotecnologia (Madrid, Spain) under specific pathogen-free conditions. All experiments were performed using mice on a C57BL/ 6 genetic background. CD $69^{-/-}$mice were backcrossed on C57BL/ 6 background 12 times. WT and CD69 $/-$ mice used for experiments were littermates or age-matched litters whose parents were littermates and were 6-13 weeks of age at the time of experimentation. All procedures involving animals and their care were approved by the Ethics Committee of the University of Madrid and were conducted according to institutional guidelines that are in compliance with the National Institutes of Health's Guide for the Care and Use of Laboratory Animals.

Induction and assessment of CIA. CFA was prepared by mixing $100 \mathrm{mg}$ of heat-killed M. tuberculosis (H37Ra, Difco, Detroit, Michigan, USA) with $20 \mathrm{ml}$ of incomplete Freund's adjuvant (Sigma-Aldrich, St. Louis, Missouri, USA). Chick CII (Sigma-Aldrich, $2 \mathrm{mg} / \mathrm{ml}$ ) was dissolved overnight at $4^{\circ} \mathrm{C}$ in $10 \mathrm{mM}$ acetic acid and combined with an equal volume of CFA. Mice were injected intradermally at the base of the tail and boosted at days 21 and 38, following a modified protocol (24). Control mice were treated with CFA without CII. The severity of arthritis was monitored by direct examination with a digital caliper according to the following scale: grade 0 , no swelling; 1 , slight swelling and erythema; 2, pronounced inflammation; and 3, joint rigidity. Each limb was graded, giving a maximum possible score of 12 per animal.

Paws to be histologically analyzed were chosen before the experiment. After sacrifice, paws were collected, fixed, decalcified, and paraffin embedded. Sections (5 $\mu \mathrm{m})$ were stained with hematoxylin and eosin and scored according to the following scale: 0 , no inflammation; 1 , slight thickening of synovial cell layer and/or some inflammatory cells in the sublining; 2 , thickening of synovial lining, infiltration of the sublining, and localized cartilage erosions; and 3 , infiltration in the synovial space, pannus formation, cartilage destruction, and bone erosion.

Cell proliferation assays. Draining $\mathrm{LN}$ and spleen cells $\left(2 \times 10^{5}\right)$ in $200 \mu \mathrm{l}$ of RPMI medium (containing 50 $\mu \mathrm{M} 2-\mathrm{ME}$ and $10 \% \mathrm{FCS}$ ) were cultured in triplicate in a 96-well plate at $37^{\circ} \mathrm{C}\left(5 \% \mathrm{CO}_{2}\right)$ for 72 hours with $0-50 \mu \mathrm{g} / \mathrm{ml}$ of denatured CII (boiled for 10 minutes). Cells were pulsed with $1 \mu \mathrm{Ci}$ per well of [methyl- ${ }^{3} \mathrm{H}$ ] thymidine $\left(\left[{ }^{3} \mathrm{H}\right] \mathrm{TdR}\right)$ (Amersham, Little Chalfont, United Kingdom) for the last 12 hours of culture before harvesting onto glass fiber filters for determination of $\left[{ }^{3} \mathrm{H}\right] \mathrm{TdR}$ uptake.

Detection of anti-CII antibodies. ELISA for antibody to CII was performed as previously described (25). HRP-conjugated secondary antibody specific for IgG1, IgG2a, IgG2b, IgG3, or IgM (Southern Biotechnology, Birmingham, Alabama, USA) and IgA (Sigma-Aldrich) were used.

Cell isolation. Positive selection of splenocyte subsets was performed using specific biotin-conjugated antibodies against $\mathrm{CD} 11 \mathrm{~b}, \mathrm{CD} 3, \mathrm{CD} 4$, and $\mathrm{CD} 8$, all from BD-Pharmingen (San Diego, California, USA), and biotin binder Dynabeads (Dynal A.S., Oslo, Norway) yielding about $98 \%$ cell purity. Mouse synovial cells were isolated from CIA WT mice as described for human synovial tissue (26), and further subset purification was performed as shown above. After positive selection of $\mathrm{CD} 11 \mathrm{~b}^{+}$and $\mathrm{CD}^{+}$synovial cells, synovial cells were incubated with biotin CD45 and negatively selected using excess of avidin-magnetic beads. The remaining CD45-negative cells were used for RNA extraction. Synovial fluid leukocytes were obtained from synovial effusions drained from the inflamed knees of patients with reactive arthritis, ankylosing spondylitis, and RA who fulfilled the American College of Rheumatology 1987 criteria (27) and were purified by Ficoll-Hypaque (Pharmacia, Uppsala, Sweden) density-gradient centrifugation.

$R$ Nase protection assay and quantitative real-time RT-PCR analyses. Joints were homogenized with a Polytron (Kinematica, Littau, Switzerland), and total RNA was isolated using the Ultraspec RNA reagent (Biotecx, Houston, Texas, USA). RNase protection assays were performed on 2.5-5 $\mu$ g of RNA using the Riboquant MultiProbe RNase Protection Assay System (PharMingen, San Diego, California, USA) according to the manufacturer's instructions. For RT-PCR, $2 \mu \mathrm{g}$ of DNaseI-treated RNA were reverse transcribed with MuLV RT (Roche Diagnostics Ltd., Lewes, United Kingdom). Real-time PCR was performed in a Lightcycler rapid thermal cycler system (Roche, Mannheim, Germany) using primers from various exons that generated products about $200 \mathrm{bp}$ in length. Results for each cytokine are normalized to GAPDH expression and measured in parallel in each sample.

Antibodies. Murine mAb specific for mouse CD69 was generated by fusion of NS-1 myeloma cells with splenocytes from a CD69-/- mouse immunized with mouse pre-B cells expressing CD69 (13). Antibodies specific for CD69 were purified and used in in vitro cytokine production assays. Mouse anti-human TP1/8 mAb has been described previously (3).

The blocking anti-TGF- $\beta$ 1D11.16.8 (mouse IgG1 hybridoma, purchased from ATCC, Manassas, Virginia, 
a
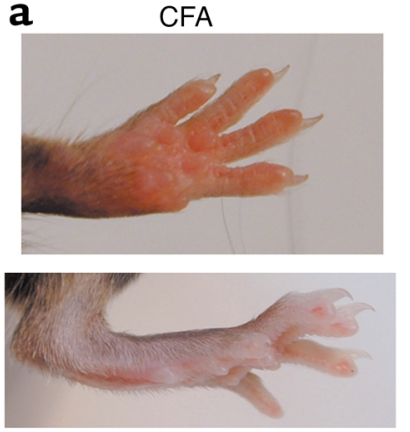

b

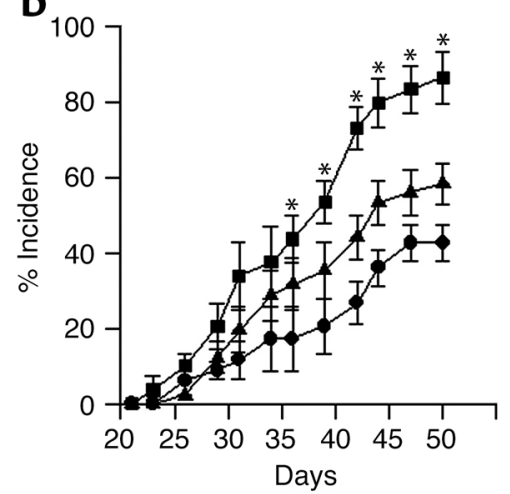

CIA-CD69+/+
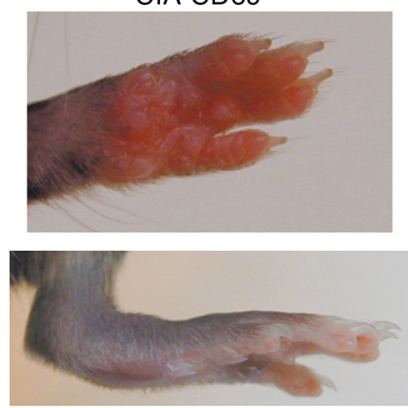
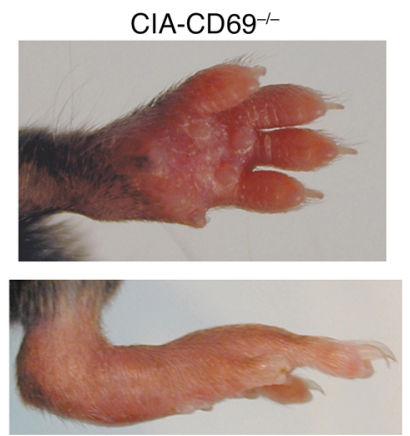

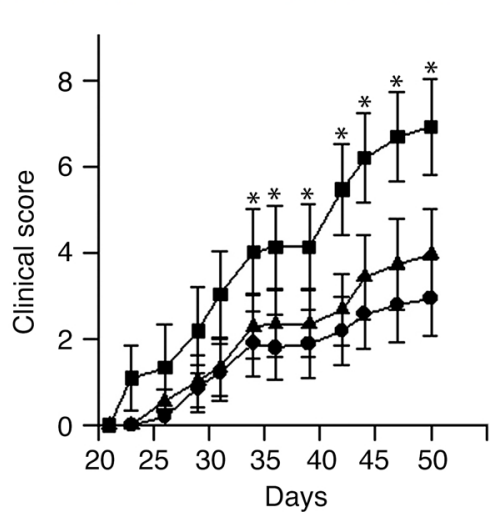

\section{Figure 1}

Exacerbated $\mathrm{ClA}$ in $\mathrm{CD}_{69}^{-/}$ mice. (a) CFA-treated control mice (left panels) are compared with representative pictures of the most severe cases of $\mathrm{CIA}$ in $\mathrm{CD} 69^{+/+}$mice and CD69-/-mice (middle and right panels, respectively). (b) Incidence of arthritis (percentage of diseased mice) and severity of clinical signs in $\mathrm{CD}^{+/++}$(circles), $\mathrm{CD}^{+/-}$(triangles), and CD69-/- (squares) mice evaluated as described in Methods. Results correspond to the arithmetic mean \pm SD from three separate experiments ( 18 mice per group per experiment). ${ }^{*} P<0.01$ versus $\mathrm{CD} 69^{+/+}$ (Student's $t$ test).
USA) (28) at $2 \mathrm{mg} / \mathrm{ml}$ in $25 \mu \mathrm{l}$ of PBS, PBS only, or an irrelevant control isotype-matched $\mathrm{mAb}$ were injected subcutaneously in one of the hind paws every 2 days after the second injection of CII (day 21), and paw inflammation was monitored.

Determination of cytokine production. To determine the levels of cytokines in washouts of joint tissue, patellas with adjacent synovium were obtained at sacrifice of the mice (day 50), in a standardized manner from knee joints as previously described (29), and incubated in RPMI-1640 medium ( $200 \mu$ l per patella) with $0.1 \%$ BSA for 1 hour at room temperature. Then, active and total TGF- $\beta 1$ (Emax ImmunoAssay System, Promega Corp.,
Madison, Wisconsin, USA) and IL- $1 \beta$, TNF- $\alpha$, and RANTES (OptEIA ELISA Sets, BD-Pharmingen) were quantified in culture supernatants.

For in vitro cytokine production, mouse splenocytes (prestimulated with $5 \mu \mathrm{g} / \mathrm{ml}$ Concanavalin A [ConA; Sigma-Aldrich] for 16 hours and then purified as described above) or synovial cells were incubated with an anti-mouse CD69, clone CD69.2.2 (mouse IgG1), or control mouse IgG1 mAb (both at $10 \mu \mathrm{g} / \mathrm{ml}$ ) plus a goat anti-mouse IgG Fc fragment-specific $\mathrm{F}\left(\mathrm{ab}^{\prime}\right)_{2}$ (Jackson Immunoresearch, West Grove, Pennsylvania, USA) at 20 $\mu \mathrm{g} / \mathrm{ml}$. Then, active and total TGF- $\beta 1$, IL- $1 \beta$, TNF- $\alpha$, and RANTES were assayed in culture supernatants after 24 $\mathbf{a}$

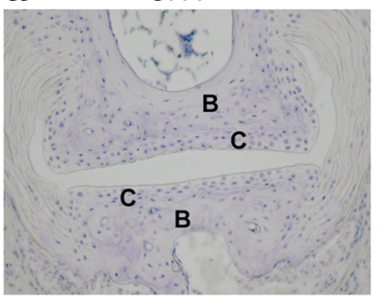

CIA-CD69 ${ }^{+/+}$

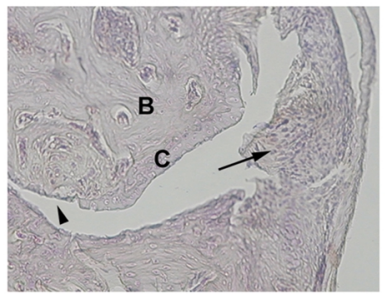

CIA-CD69-/-

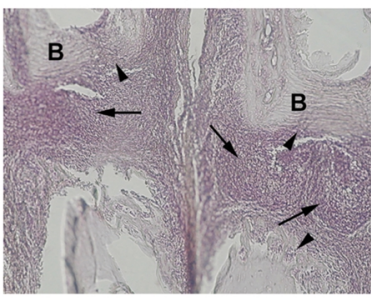

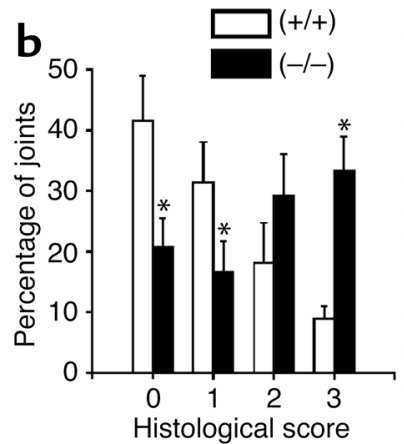

\section{Figure 2}

Histological assessment of CIA in CD69-deficient mice. (a) Representative section of joint histopathology on whole paws of control (CFA, left panel, $\times 100$ ) and Cll-immunized CD69+/+ (middle panel, $\times 100)$ and CD69-/- (right panel, $\times 60$ ) mice. Arrowheads indicate cartilage and bone erosions, and arrows indicate leukocyte infiltrates and pannus. C, cartilage; B, bone. (b) Scoring of inflammation, cartilage damage, pannus formation, and bone erosion of paws from $\mathrm{CD}^{+/+}$(white bars) and CD69-/- (black bars) mice as described in Methods. Results are expressed as the arithmetic mean \pm SD of the percentage of joints ascribed to each severity group from three independent experiments (eight mice per group per experiment); ${ }^{*} P<0.01$ versus $\mathrm{CD} 69^{+/+}$(Mann-Whitney $U$ test). 
hours, as above. For cytokine production by human cells, we used human synovial fluid leukocytes from patients with inflammatory joint diseases, purified as described above, and stable transfectants of CD69 in the Jurkat leukemic $\mathrm{T}$ cell line, which was previously characterized (30). Cells were treated at $10^{6}$ cells per milliliter with the anti-human CD69 TP1/8 or with an isotype control $\mathrm{mAb}$, with or without cross-linking. TGF- $\beta 1$ was assayed in culture supernatant after 24 hours, as above.

\section{Results}

CD69-deficient mice develop an exacerbated form of CIA. To explore the role of CD69 in a model of chronic autoimmune arthritis, we compared interbred B6 WT and CD69-/- mice (12) for incidence and severity of CIA induced by intradermal immunization with CII in CFA, which elicits a moderate arthritis in B6 mice (24). CD69-deficient mice developed an exacerbated form of CIA, with severe swelling of the footpad, ankle and wrist joints, and digits (Figure 1a) and significantly higher incidence and severity than in WT mice (Figure 1b). Furthermore, $\mathrm{CD} 69^{+/-}$mice, which express intermediate levels of CD69 (12), showed a higher incidence and severity of CIA than WT mice but significantly lower than $\mathrm{CD} 69^{-/-}$mice (Figure $1 \mathrm{~b}$ ).

To further evaluate arthritis, hematoxylin- and eosin-stained sections of paws from CD $69^{-/-}$and WT mice with different grades of CIA were assessed by histological analyses. These studies paralleled the results shown for clinical evaluation, with a significantly higher percentage of joints with severe pathology observed in CD69-/- mice than in WT mice (Figure 2a). Joints from CD69-deficient mice more frequently showed widespread infiltration of inflammatory cells, with pannus tissue extending from the marginal zones to the cartilage and through the medulla of subchondral bone (Figure 2, a and b). In late-stage disease, there was destruction of articular cartilage and bone, with loss of normal joint architecture. Therefore, these results showed a clear-cut inverse correlation between CIA severity and expression of CD69, suggesting an in vivo inhibitory role for CD69 in CIA development.
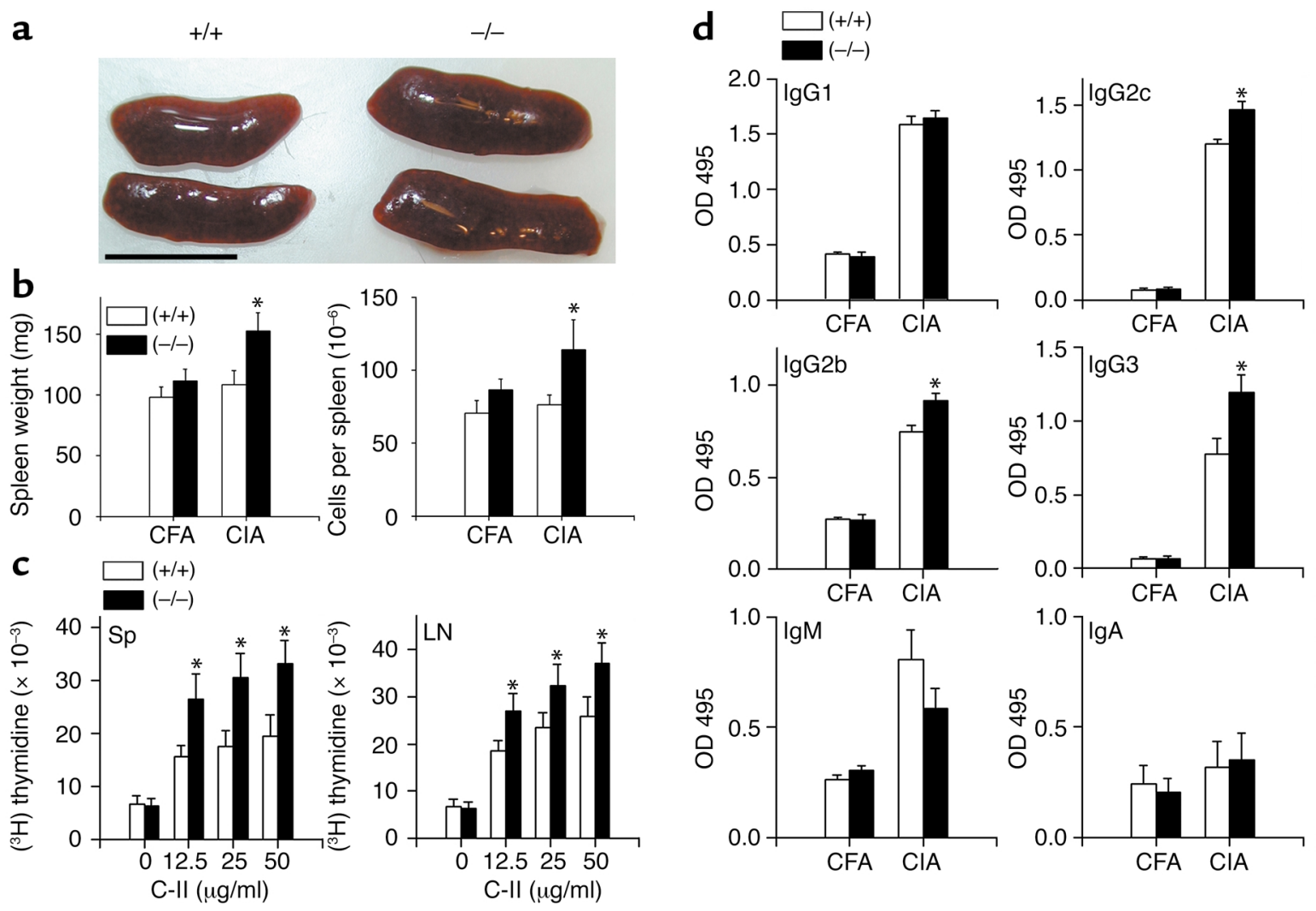

\section{Figure 3}

Enhanced Cll-specific immune response in CD69-/- mice. (a) Enlarged spleens of CD69-/- compared with CD69+/+ mice. Scale bar: $1 \mathrm{~cm}$. (b) Spleen weight and cell number (arithmetic mean \pm SD) from CFA control and CII-immunized (CIA) CD69 ${ }^{+/}$(white bars) and CD69-/- (black bars) mice are shown. ${ }^{*} P<0.01$ versus WT immunized mice (Student's $t$ test). (c) Proliferation of spleen and LN cells from CII-immunized $\mathrm{CD} 9^{+/+}$(white bars) and CD69-/- (black bars) mice stimulated with different concentrations of inactivated CII ( $x$ axis). Data correspond to the arithmetic mean $\pm \mathrm{SD}$ of $\left[{ }^{3} \mathrm{H}\right] \mathrm{TdR}$ uptake in three independent experiments. ${ }^{*} P<0.01$ versus $\mathrm{CD} 69^{+/+}$(Mann-Whitney $U$ test). Sp, spleen. (d) Increments of CII-specific Th1-dependent isotypes in CD69-/- mice. Cll-specific IgG1 and IgG2b (1:20,000 serum dilution), IgG2c and $\operatorname{lgG} 3$ (1:5,000 serum dilution), and IgM and $\lg A$ (1:200 serum dilution) antibody levels in sera collected at sacrifice (day 50) of CFA-treated control or Cll-immunized (CIA) CD69+/+ (white bars) and CD69-/- (black bars) mice. Data are represented as the arithmetic mean \pm SD of absorbance units at $495 \mathrm{~nm}$ in three separate experiments (10 mice per group per experiment). ${ }^{*} P<0.01$ versus CD69 ${ }^{+/+}$(Student's $t$ test). 

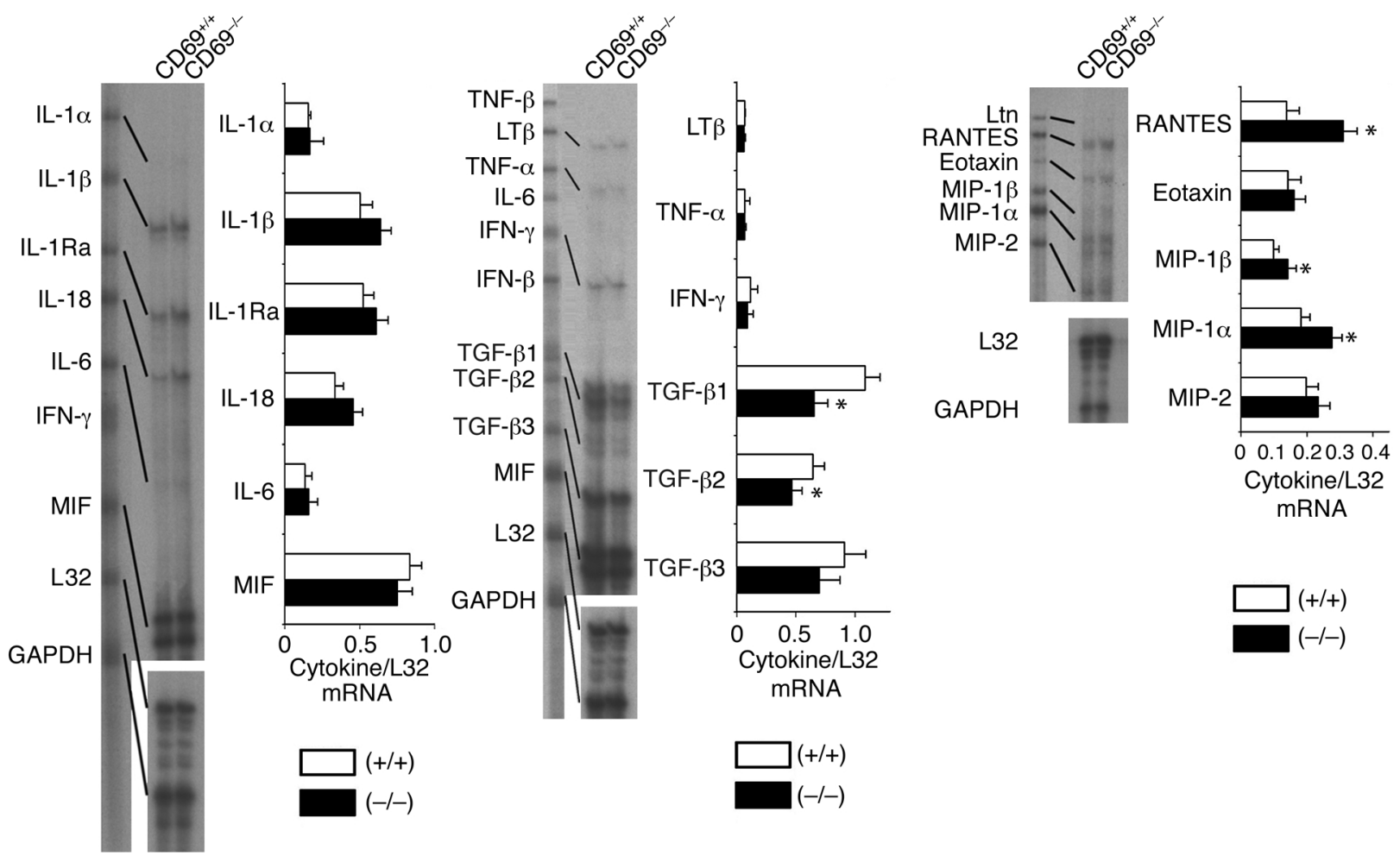

Figure 4

Local cytokine mRNA analysis in Cll-immunized CD69-/- mice. mRNA analysis of CIA CD69 $9^{+/}$(white bars) and CD69-/- (black bars) mouse hind paws. Each lane corresponds to the mRNA pool of six mice per group, and each bar represents similar experiments (six mice per group per experiment). Results are expressed in arbitrary densitometric units normalized for expression of the ribosomal housekeeping protein L32 in each sample (arithmetic mean $\pm \mathrm{SD}$ of four separate experiments). ${ }^{*} P<0.01$ versus $\mathrm{CD} 69^{+/+}$(Mann-Whitney $U$ test). MIF, macrophage inhibitory factor; LT $\beta$, lymphotoxin- $\beta$; Ltn, lymphotoxin.

Enhanced collagen type II-specific immune response in CD69- ${ }^{--}$mice. These results strongly suggested that CII triggers an exacerbated immune response in CD69- $/$ mice. Accordingly, the spleen was significantly enlarged in $\mathrm{CD} 69^{-/-} \mathrm{CII}-$ challenged mice (about 1.4-fold heavier, $P<0.001, t$ test) as compared with WT mice at 13 weeks of age, suggesting a higher activation of the immune system in arthritic CD69-/- mice (Figure 3, a and b). The increase in spleen weight correlated with an increased cellularity (Figure 3b). Next, we ascertained whether this increment in cellularity was due to a difference in any subpopulation of immune cells present in the spleen. The proportion of T cells, B cells, macrophages, and NK cells as well as the CD4/CD8 ratio, the naive/effector-memory cell ratio (CD62L/CD44), and the proportions of $\mathrm{CD} 45 \mathrm{RB}^{\text {low }} \mathrm{CD} 25^{+} \mathrm{CD} 4^{+}$regulatory $\mathrm{T}$ cells were analyzed. The proportion of these subsets was conserved between WT and CD69-/- mice either in the absence of any stimulation or after CII challenge (data not shown).

To assess lymphocyte reactivity, we analyzed the CII-specific proliferative response of lymphocytes from spleen and lymph nodes. Lymphocytes from CD69-/mice proliferated to a significantly higher extent than those from WT mice at the different doses of CII test- ed (Figure 3c), indicating an inhibitory influence of CD69 in the CII-specific proliferation of immune cells from CII-challenged mice.

We next investigated the humoral response to CII. Analyses of serum concentration of anti-CII isotypes showed significantly augmented levels of the Th1dependent isotypes $\operatorname{IgG} 2 \mathrm{c}$, which is equivalent in B6 mice to IgG2a, and IgG2b (Figure 3d). A significant increment in IgG3 was also found, indicating B cell hyperresponsiveness in $\mathrm{CD} 69^{-/-}$mice, while the reduction in IgM would suggest enhanced shift to IgG. The Th-2-dependent IgG1 was not significantly different, and CII did not induce a significant IgA response. Altogether, these results suggest a stronger $\mathrm{T}$ and $\mathrm{B}$ cell immune reactivity in CD69-deficient mice.

CD69-deficient mice show diminished local TGF- $\beta 1$ production. A wide array of cytokines are involved in inflammation and development of arthritis $(15,31,32)$. Since the joints are the most relevant site of cytokine production in arthritis, we tested how CD69 deficiency could affect the profile of cytokine expression in joints of mice with CIA. RNase protection assays showed that CD69 deficiency enhanced mRNA expression of some inflammatory mediators such as IL- $1 \beta$, RANTES, macrophage inflammatory protein- $1 \alpha$ (MIP-1 $\alpha$ ), and MIP-1 $\beta$ (Figure 4). However, the most 

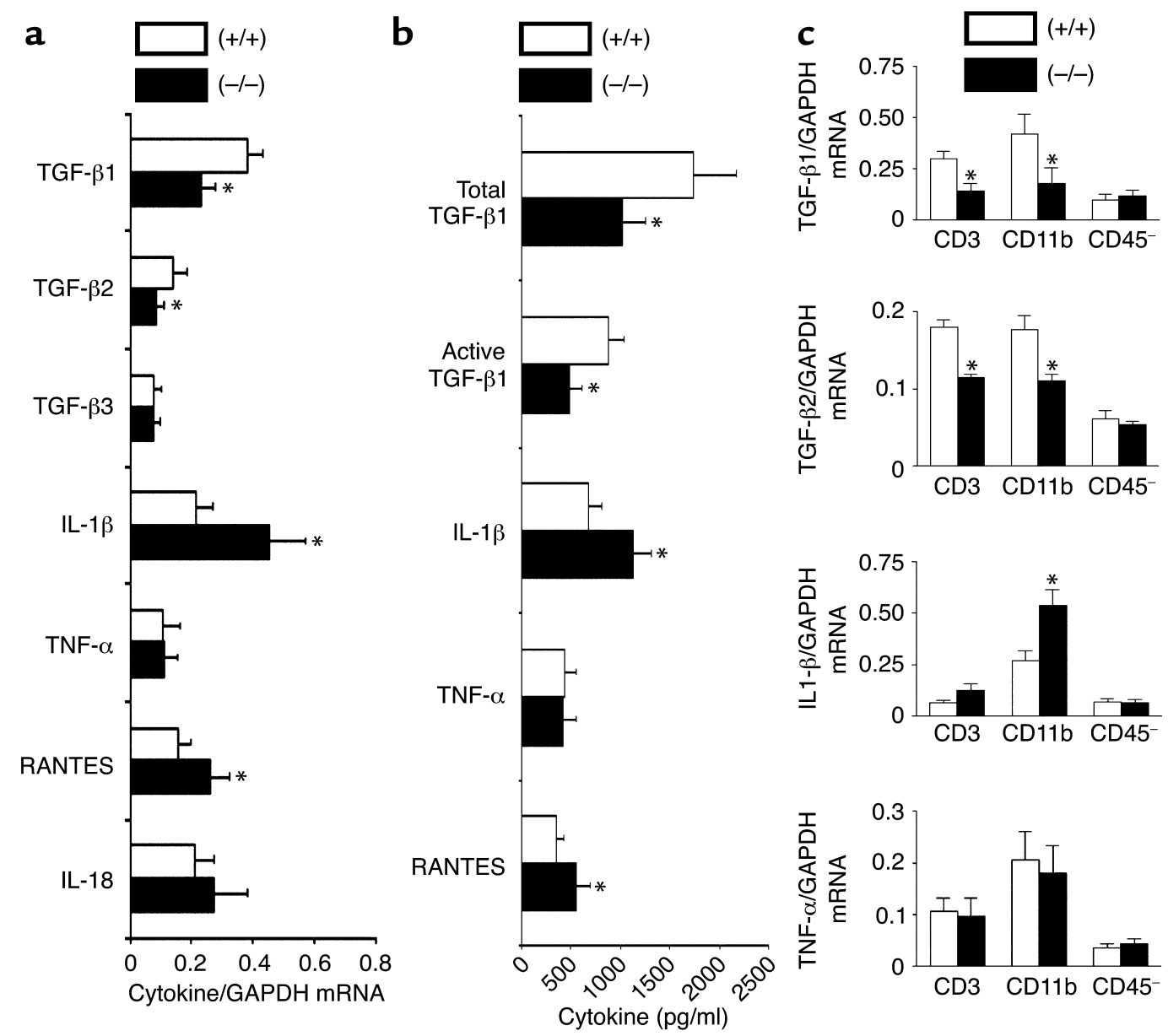

\section{Figure 5}

Local cytokine analysis in joints and purified leukocyte synovial cells from Cll-immunized CD69-/- mice. (a) Real-time quantitative RT-PCR analysis of mRNA from CD69 ${ }^{++}$(white bars) and CD69-/- (black bars) mouse hind paws. Each bar represents the arithmetic mean \pm SD of 12 mice per group in two independent experiments. Results for each cytokine are normalized to GAPDH expression measured in parallel in each sample. ${ }^{*} P<0.01$ versus CD69 ${ }^{+/+}$(Mann-Whitney $U$ test). (b) Levels of active and total TGF- $\beta 1$, IL- $1 \beta$, TNF- $\alpha$, and RANTES in synovial

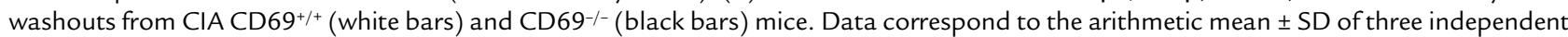
experiments (six mice per group per experiment). ${ }^{*} P<0.01$ versus $C D 69^{+/+}$(Mann-Whitney $U$ test). (c) Quantitative RT-PCR analysis of mRNA from $\mathrm{CD}_{69}{ }^{+/+}$(white bars) and CD69-/- (black bars) purified subsets of synovial cells. Each histogram represents the arithmetic mean \pm SD of 12 mice per group in two independent experiments. Results of each cytokine are normalized to GAPDH expression measured in parallel in each sample. ${ }^{*} P<0.01$ versus $\mathrm{CD} 69^{+/+}$(Mann-Whitney $U$ test).

significant difference was the reduction in mRNA levels of the anti-inflammatory cytokines TGF- $\beta 1$ and TGF- $\beta 2$ in CD $69^{-/-}$mice (Figure 4). Real-time quantitative RT-PCR analyses confirmed the reduction in joint mRNA for TGF- $\beta 1$ and TGF- $\beta 2$ and the increase in IL-1 $\beta$ and RANTES (Figure 5a).

We next determined the levels of active and total TGF- $\beta 1$ protein, directly produced by activated leukocytes (33), and other cytokines in washouts of joint tissue from CIA-challenged mice at sacrifice. In contrast to the unchanged systemic levels of TGF- $\beta 1$ (data not shown), active and total TGF- $\beta 1$ levels in the synovial washouts were significantly reduced in CD69-deficient mice (Figure 5b). In contrast, proinflammatory cytokines such as IL- $1 \beta$ and RANTES were increased in synovial washouts from $\mathrm{CD} 69^{-/-}$ mice as compared with WT mice, whereas TNF- $\alpha$ lev- els remained locally unchanged (Figure $5 b$ ). Since TGF- $\beta 1$ is considered an anti-inflammatory cytokine with a predominant protective role in CIA (20), these results suggest that deficient local production of this cytokine may account for the enhanced inflammatory response observed in $\mathrm{CD} 69^{-/-}$mice through the augmented production of IL-1 $\beta$ and various chemokines, thus altering the balance between pro- and antiinflammatory cytokines at synovium (15).

To ascertain the cell population responsible for the pattern of cytokine expression seen in $\mathrm{CD} 69^{-/-}$mice, we purified synovial cells from CIA-challenged mice. Synovial cells were mainly $\mathrm{CD} 11 \mathrm{~b}^{+}$macrophages $(66.3 \% \pm 29.4 \%)$, with some $\mathrm{CD}^{+}$cells $(9.6 \% \pm 5.3 \%)$ and nonleukocyte CD $45^{-}$cells $(24.1 \% \pm 14.8 \%)$. The three subsets were isolated, and quantitative RT-PCR revealed that both $\mathrm{CD}^{+}$ and $\mathrm{CD} 11 \mathrm{~b}^{+}$leukocytes contributed to the decrease in 

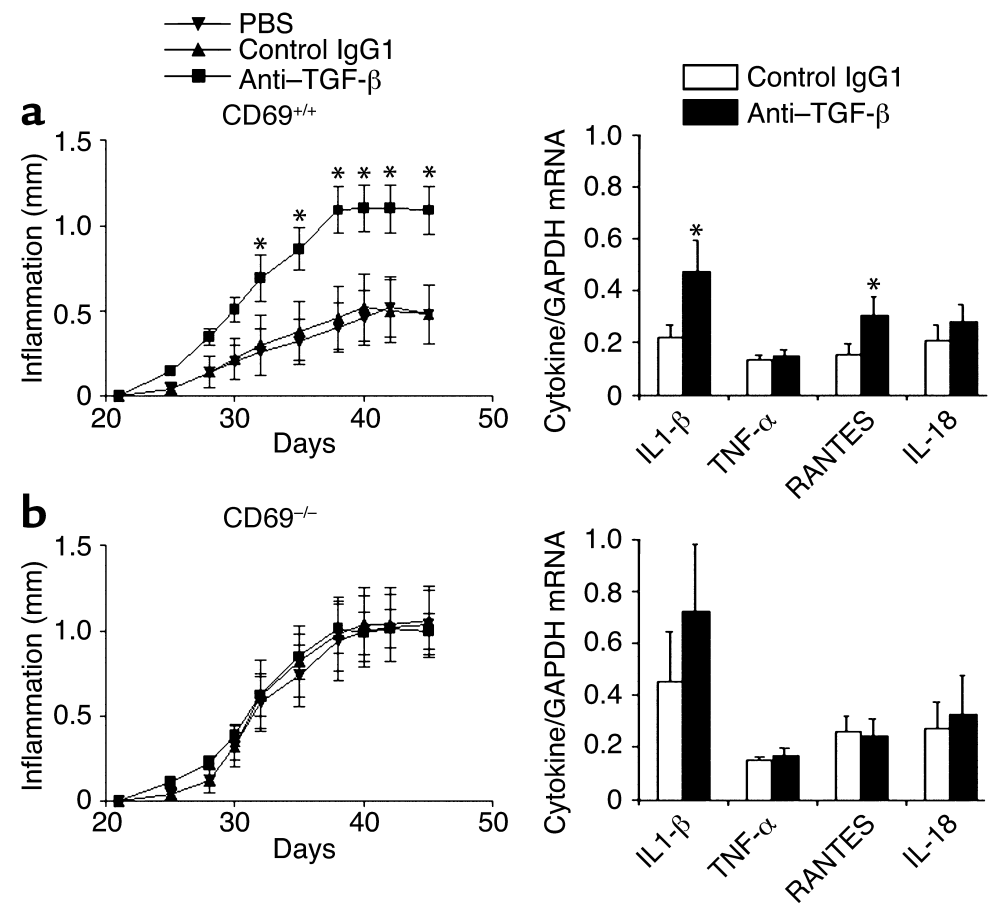

\section{Figure 6}

Effect of a blocking anti-TGF- $\beta$ antibody in WT and CD69-deficient mice. (a) As shown in the left panel, $\mathrm{CD} 69^{+/+}$mice were treated from day 21 (second immunization) with the blocking anti-TGF- $\beta$ antibody (squares), the isotype control IgG1 (triangles), or the carrier (inverted triangles). Paw inflammation measured with a precision caliper is expressed in millimeters of inflammation with respect to day 21. Results express the arithmetic mean \pm SD of 12 mice per group in two independent experiments. On the right, analysis by quantitative real-time RT-PCR of mRNA from paws treated with isotype control antibody (white bars) or with anti-TGF- $\beta$ (black bars) is shown. Each bar represents the arithmetic mean \pm SD of 12 mice per group in two independent experiments. Results of each cytokine are normalized to GAPDH expression measured in parallel in each sample. ${ }^{*} P<0.01$ versus control antibody (Mann-Whitney $U$ test). (b) $\mathrm{CD} 69^{-/-}$mice were treated as in a, paw inflammation was measured (left panel), and mRNA was determined (right panel) as above.
TGF- $\beta$ levels in CD69-deficient mice (Figure 5c). Nevertheless, the $\mathrm{CD} 11 \mathrm{~b}^{+}$subset was responsible for the subsequent higher proinflammatory response mediated by IL-1 $\beta$ (Figure 5c), most likely playing a crucial role in the perpetuation of synovitis.

Blockade of TGF- $\beta$ increases CIA severity in WT but not in CD69-deficient mice. The protective effects of TGF- $\beta 1$ in CIA could explain by themselves the deregulation of the balance of some proinflammatory and chemotactic cytokines $(15,20,21)$. These results would explain the higher infiltration of leukocytes and the inflammatory response in joints from CD69-deficient mice. To establish a functional link between TGF- $\beta$ activity and CIA severity, a blocking anti-TGF- $\beta$ antibody (28) was locally injected in paws from CIA WT mice. TGF- $\beta$ blockade induced a significant increase in paw inflammation as compared with control antibody or carrier (Figure 6a). Joint mRNA analysis by quantitative RT-PCR showed a significant increase in IL- $1 \beta$ and RANTES but not in TNF- $\alpha$ and IL-18 (Figure 6a). These results indicate that TGF- $\beta$ blockade in CIA WT mice results in a similar phenotype to that seen in CD69-deficient mice.

In contrast, local injection of anti-TGF- $\beta$ in CIA CD69 $/-$ mice did not further enhance paw inflammation (Figure 6b). Accordingly, mRNA analyses showed no significant modification in the mRNA levels for proinflammatory cytokines. These findings reveal that TGF- $\beta$ blockade and CD69 deficiency do not cooperate to increase CIA severity, suggesting their interdependence.

Induction of TGF- $\beta 1$ production by $C D 69$ engagement. To analyze whether CD69 is able to regulate TGF- $\beta 1$ synthesis, we examined production of TGF- $\beta 1$ after CD69 engagement in ConA-activated mouse spleno- cytes (Figure 7a). CD69 cross-linking markedly induced total and active TGF- $\beta 1$ production in various leukocyte cell subsets (Figure 7a), concurring with data on NK cells and anti-CD3-activated splenocytes (13). Moreover, CD69 cross-linking triggered TGF- $\beta 1$ production in infiltrating synovial cells from WT mice with CIA, most of them $\mathrm{CD} 11 \mathrm{~b}^{+}$cells bearing CD69 (Figure 7b). In contrast, we did not detect any differences in synthesis of TNF- $\alpha$, RANTES, or IL-1 $\beta$ after CD69 cross-linking (data not shown).

To ascertain whether these results could be extended to humans, we analyzed TGF- $\beta 1$ production in $\mathrm{CD} 9^{+}$ synovial mononuclear cells from patients with inflammatory joint diseases (Figure 8a). Cross-linked, but not soluble, anti-CD69 induced TGF- $\beta 1$ synthesis independently of further costimulus (Figure 8a), whereas no differences were found for other cytokines such as TNF- $\alpha$ or IL-6 (data not shown). In CD69-mediated TGF- $\beta 1$ production assays, increased active TGF- $\beta 1$ correlated with total TGF- $\beta 1$ synthesis (Figures 7 and 8). These results demonstrate that, both in mice (Figure 7) and humans (Figure 8), there is a direct link between CD69 engagement and TGF- $\beta 1$ synthesis, and they may explain the higher TGF- $\beta 1$ levels found in $\mathrm{CD} 69^{+/+}$mice than in $\mathrm{CD} 69^{-/-}$mice.

To establish a direct connection between CD69 crosslinking and TGF- $\beta 1$ production, we took advantage of Jurkat T cells stably transfected with human CD69 (JKCD69). The CD69 expressing JK-CD69 produced significant active TGF- $\beta$ after cross-linking with antiCD69 antibodies, in contrast with the absence of TGF- $\beta$ synthesis in the parental CD69-negative Jurkat $\mathrm{T}$ cell line (Figure $8 \mathrm{~b}$ ). In addition, our data showed that cross-linking of CD69 failed to induce TNF- $\alpha$ 
a

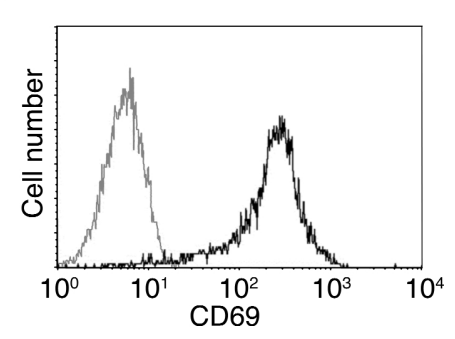

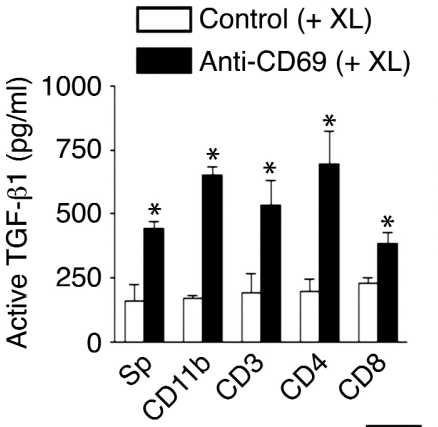

b
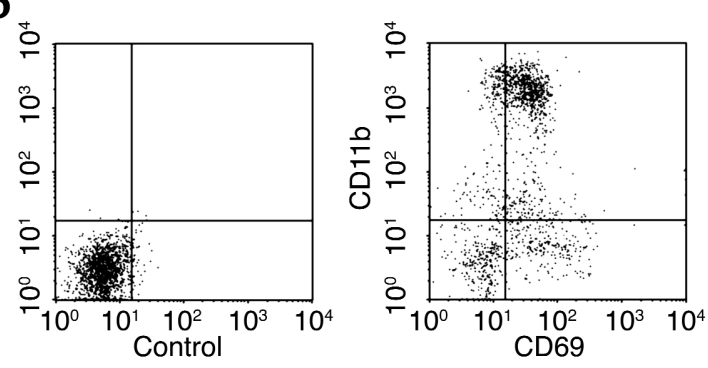

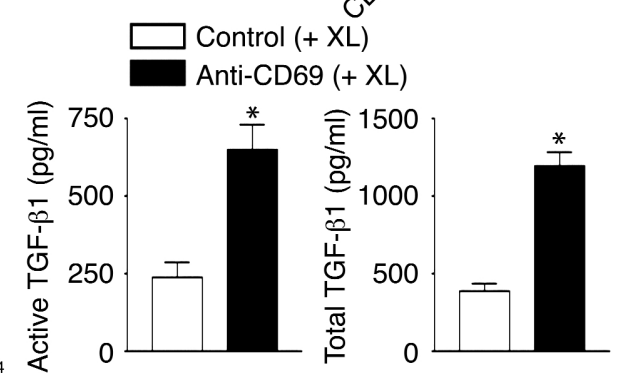

Figure 7

CD69 engagement induces TGF- $\beta 1$ secretion in mouse splenocytes and synovial leukocytes from CIA mice. (a) ConA-stimulated splenocytes were stained for CD69 (solid line, left panel) and an isotype-matched antibody (dotted line, left panel). Activated splenocytes were then purified in different subsets and treated with an anti-mouse CD69 (black bars) or an isotype-matched control antibody (white bars), and a cross-linking secondary antibody was added. Active and total TGF- $\beta 1$ were determined (right panel). (b) Mouse synovial cells from CIA mice were stained for CD11b and CD69 (middle panel) or isotype control antibodies (left panel). Synovial cells were treated as in a, and active and total TGF- $\beta 1$ was determined (right panel). Results in $\mathbf{a}$ and $\mathbf{b}$ are expressed as the arithmetic mean \pm SD of four independent experiments. ${ }^{*} P<0.01$ versus control antibody (Mann-Whitney $U$ test). $\mathrm{XL}$, cross-linker.

production (Figure $8 \mathrm{~b}$ ). Taken together, these results establish that CD69, a receptor expressed after activation, downregulates the autoimmune response and the inflammatory reaction through direct secretion of active TGF- $\beta$ at inflammatory foci.

\section{Discussion}

Susceptibility to autoimmune diseases is conferred by a variety of genetic and environmental factors. Several autoimmune susceptibility gene clusters have been identified in human and mouse $(34,35)$. Interestingly, the CIA 3 quantitative trait loci on rat chromosome 4 and murine chromosome 6 , syntenic to human $12 \mathrm{p} 12$ p13, contains susceptibility loci for several autoimmune diseases, including RA $(36,37)$. Since the CD69 gene is located in this region $(38,39)$, this receptor may be involved in the pathogenesis of CIA. Accordingly, the high and persistent expression of CD69 in chronic inflammatory infiltrates $(7,8)$ suggests an important role for this molecule in the immune reactivity and the inflammatory reaction. CIA provides a suitable model for exploring CD69 function in the development and perpetuation of chronic inflammatory conditions. Here, we provide evidence that CD69 has an inhibitory role in CIA pathogenesis. Under specific conditions that generate a moderate CIA in B6 WT mice $(24,32)$, CD69-deficient mice develop an exacerbated form of CIA. This condition correlates with a higher immune reactivity characterized by an enlarged spleen with increased cellularity and enhanced CII-specific $T$ and $B$ cell responses. This altered immune reactivity observed in CD69-/- mice leads to the synthesis of Th1-dependent anti-CII antibodies (IgG2c, IgG2b) involved in the pathogenesis of CIA (40).

Our data show a significant reduction in TGF- $\beta 1$ expression in joints from CD69-/- mice, accompanied by an increase in some inflammatory mediators, such as IL-1 $\beta$, RANTES, MIP-1 $\alpha$, and MIP-1 $\beta$. However, no significant enhancement in TNF- $\alpha$ was observed. Although this cytokine is an important mediator of inflammation in arthritis (41), our results indicate that there are alternative pathways of inflammation in which TNF- $\alpha$ does not have a predominant role. Our data are in agreement with previous reports showing that TNF- $\alpha$ is not essential to the development of arthritis $(42,43)$, since there is severe inflammatory arthritis in the absence of TNF- $\alpha$ (32). In these arthritis mouse models, IL-1 $\beta$ exerted a key role in mediating inflammation. Similarly, in humans, TNF- $\alpha$ therapy alone or with concomitant methotrexate is effective in no more than $40 \%$ of patients with RA at 30 weeks of treatment (American College of Rheumatology $50 \%$ improvement criteria) $(44,45)$, and IL- $1 \beta$ inhibitors have a moderate effect (46). These results suggest the importance of the balance between proand anti-inflammatory cytokines, which is not dependent on a single cytokine (15). Disruption of the tightly controlled cytokine network by TGF- $\beta 1$ down- 

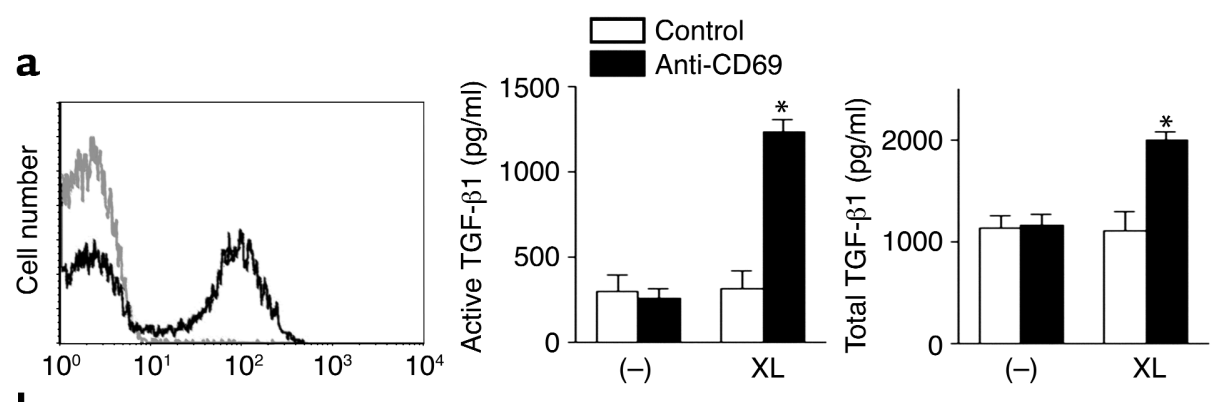

b

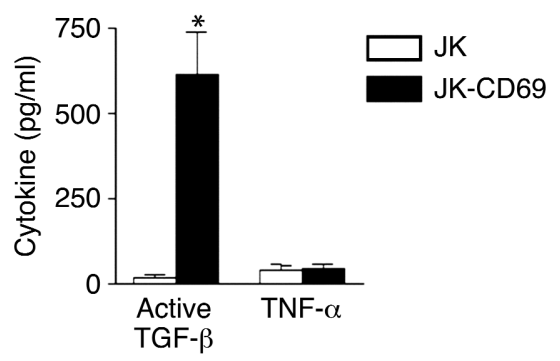

\section{Figure 8}

CD 69 cross-linking induces TGF- $\beta 1$ production in human synovial leukocytes and in a human CD69 T cell stable transfectant. (a) Human synovial leukocytes from patients with RA were stained for CD69 (solid line, left panel) and isotype-matched antibody (dotted line, left panel). Synovial leukocytes were treated with anti-human CD69 (black bars) or an isotype-matched control antibody (white bars) in the presence $(\mathrm{XL})$ or absence $(-)$ of a cross-linking secondary antibody, and active and total TGF- $\beta 1$ were determined (right). ${ }^{*} P<0.01$ versus control antibody (Mann-Whitney $U$ test). These results are representative of similar data obtained on synovial leukocytes from patients with reactive arthritis or ankylosing spondylitis. (b) Jurkat human T cell leukemic cell line (dotted line, left panel) and CD69 stable transfectants (solid line, left panel) were stained for CD69. Production of TGF- $\beta 1$ but not TNF- $\alpha$ by CD69 engagement is shown in the right panel. The human T lymphoblastoid cell line Jurkat (JK) (white bars) and the stable transfectant expressing CD69 (JK-CD69) (black bars) were treated for 24 hours with cross-linked anti-CD69. Results in $\mathbf{a}$ and $\mathbf{b}$ are expressed as the arithmetic mean \pm SD of four independent experiments. ${ }^{*} P<0.01$ versus the parental JK cell line (Mann Whitney $U$ test).

regulation results in enhanced immune reactivity and induction of autoimmunity $(15,19,23)$. Our findings reveal that local TGF- $\beta$ blockade leads to enhanced CIA and increased expression of IL- $1 \beta$ and RANTES in WT mice, establishing a direct link between TGF- $\beta$ downregulation and increased paw inflammation. Moreover, TGF- $\beta$ blockade does not increase CIA severity in CD69-deficient mice, suggesting the interdependence of both processes and the importance of the balance of TGF- $\beta$ levels in the final outcome of inflammation. Our results are in agreement with previous reports showing that TGF- $\beta 1$ has a protective role against the immune response that mediates CIA (20) and other inflammatory processes (23), such as experimental allergic encephalomyelitis (47), colitis (48), and autoimmune diabetes (49). In addition, TGF- $\beta 1$ null mice develop a lethal autoimmune-like process $(16,17)$, and the abrogation of TGF- $\beta$ signaling in $\mathrm{T}$ cells leads to autoimmune disease (50). Finally, previous results in B cells defective for TGF- $\beta$-mediated signaling (51) concur with our data on high levels of antiCII IgG3 antibodies in CD69-/- mice, which reveal B cell hyperresponsiveness.

Our in vivo results show that CD69 exerts an inhibitory effect on CIA and strongly suggest that this molecule functions as a negative regulator of the immune response and the inflammatory reaction. This is in accordance with the role of CD69 in NK cell-mediated tumor rejection (13). The induction of TGF- $\beta 1$ synthesis after CD69 engagement establishes a possible mechanism through which $\mathrm{CD} 69$ regulates the autoimmune response. Previous in vitro results showed that soluble anti-CD69 antibodies enhanced the $\mathrm{T}$ cell proliferation induced by suboptimal doses of PMA (3). However, other anti-CD69 antibodies inhibited IL-1-dependent T cell proliferation (2). Similar opposing effects have been reported for cytoxic T-lymphocyte-associated antigen-4 (CTLA-4), a receptor that has a clear-cut negative regulatory effect on the immune response in vivo. Anti-CTLA-4 antibodies promote $\mathrm{T}$ cell proliferation in soluble form, yet they actively block lymphocyte proliferation and induce TGF- $\beta 1$ production when crosslinked $(52,53)$. Moreover, our data show that CD69 cross-linking without further costimulation promotes TGF- $\beta 1$ but not TNF- $\alpha$ synthesis. The reported effect of anti-CD69 on TNF- $\alpha$ production in vitro required the presence of phorbol esters $(30,54)$. Moreover, CD69 engagement in CD69-transfected Jurkat T cells mediated TGF- $\beta$ production but not TNF- $\alpha$ synthesis. In addition, it has been suggested that CD69 putative ligand(s) would mediate TNF- $\alpha$ synthesis through the interaction with CD69 (55). Therefore, although our results demonstrate that $\mathrm{CD} 69$ acts as a negative regulatory receptor in vivo, this molecule may have a complex role in TNF- $\alpha$ production that would be redundant in CD69-deficient mice (e.g., the putative ligand could be shared with 
another molecule) and would suggest a very fine tuning of pro- and anti-inflammatory cytokines (15).

It is evident that the involvement of CD69 in TGF- $\beta 1$ synthesis would be restricted to the leukocyte subsets expressing this molecule in chronic inflammation namely, infiltrating $\mathrm{T}$ cells and macrophages. A significant fraction of RA synovial leukocytes persistently express CD69 (7), and these cells are partially hyporesponsive (56). TGF- $\beta 1$, which is present in the synovium (57), would inhibit the immune response (58), and CD69 may play an important role in TGF- $\beta 1$-mediated immunosuppression in vivo. Our data show that CD69-bearing human synovial mononuclear cells from inflamed joints secrete active TGF- $\beta 1$ after CD69 cross-linking without further costimulus. It is thus feasible that in vivo the interaction of CD69 with its putative ligand(s) leads to TGF- $\beta 1$ production and attenuation of the immune/inflammatory response. Serum IgG anti-CD69 autoantibodies have been detected in a proportion of patients with RA, correlating with disease severity (59). We could hypothesize that these autoantibodies block the interaction of CD69 with its ligand, reducing TGF- $\beta 1$ production and resulting in a more severe disease. In addition, any defect in the expression or molecular alteration of the putative CD69 ligand may also result in deficient TGF- $\beta 1$ synthesis. On the other hand, agonistic antiCD69 antibodies, which would induce local TGF- $\beta 1$ secretion, may represent a novel approach for the therapy of chronic inflammation, avoiding the detrimental effects of systemic TGF- $\beta 1$ upregulation (23).

Our results support a novel role for CD69 as a molecule induced early after lymphocyte activation that triggers an inhibitory feedback loop mediated through TGF- $\beta 1$ production to control the immune reactivity and the inflammatory phenomenon. Given the highly pleiotropic nature of TGF- $\beta 1$, its synthesis driven through CD69 could restrict its activity to local antigenic stimulation sites, where it may play an important role in the suppression of autoimmune diseases. Further work is necessary to determine whether agonist anti-CD69 or the unknown ligand could be used effectively as therapeutic tools to dampen the immune response specifically at inflammatory foci.

\section{Acknowledgments}

We thank R. González-Amaro and L. Del Peso for critical reading of the manuscript. We are very grateful to I. González-Alvaro, C. Domínguez, and A.M. Ortiz for human synovial samples and helpful discussion; J.P. López-Bote and M. Delgado for advice in extracting murine synovial tissue; and M.C. Castellanos and E. Lara-Pezzi for advice about real-time RT-PCR. We also thank P. Pallares, L. Gómez, M.T. Cueva, and A. Naranjo for their excellent work at the animal facilities and C. Mark for editorial assistance. This work was supported by grants BMC02-00536 and Ayuda a la Investigación Básica 2002 de la Fundación Juan March to F. SánchezMadrid. D. Sancho and M. Gómez were supported, respectively, by grants BEFI 01/9191 and FIS 01/3016 from Instituto de Salud Carlos III (Ministerio de Sanidad y Consumo). The Department of Immunology and Oncology was founded and is supported by the Spanish Council for Scientific Research (CSIC) and by the Pharmacia Corporation.

1. Hara, T., Jung, L.K., Bjorndahl, J.M., and Fu, S.M. 1986. Human T cell activation. III. Rapid induction of a phosphorylated $28 \mathrm{kD} / 32 \mathrm{kD}$ disulfide-linked early activation antigen (EA 1) by 12-o-tetradecanoyl phorbol-13-acetate, mitogens, and antigens. J. Exp. Med. 164:1988-2005.

2. Cosulich, M.E., Rubartelli, A., Risso, A., Cozzolino, F., and Bargellesi, A. 1987. Functional characterization of an antigen involved in an early step of T-cell activation. Proc. Natl. Acad. Sci. U. S. A. 84:4205-4209.

3. Cebrian, M., et al. 1988. Triggering of T cell proliferation through AIM, an activation inducer molecule expressed on activated human lymphocytes. J. Exp. Med. 168:1621-1637.

4. Testi, R., D’Ambrosio, D., De Maria, R., and Santoni, A. 1994. The CD69 receptor: a multipurpose cell-surface trigger for hematopoietic cells. Immunol. Today. 15:479-483.

5. Sancho, D., Yanez-Mo, M., Tejedor, R., and Sanchez-Madrid, F. 1999. Activation of peripheral blood $\mathrm{T}$ cells by interaction and migration through endothelium: role of lymphocyte function antigen- 1 /intercellular adhesion molecule-1 and interleukin-15. Blood. 93:886-896.

6. Sanchez-Mateos, P., et al. 1989. Expression of a gp33/27,000 Mw activation inducer molecule (AIM) on human lymphoid tissues. Induction of cell proliferation on thymocytes and B lymphocytes by anti-AIM antibodies. Immunology. 68:72-79.

7. Laffon, A., et al. 1991. Upregulated expression and function of VLA-4 fibronectin receptors on human activated T cells in rheumatoid arthritis. J. Clin. Invest. 88:546-552.

8. García-Monzón, C., et al. 1990. Expression of a novel activation antigen on intrahepatic $\mathrm{CD}^{+} \mathrm{T}$ lymphocytes in viral chronic active hepatitis. Gastroenterology. 98:1029-1035.

9. Testi, R., Phillips, J.H., and Lanier, L.L. 1989. T cell activation via Leu-23 (CD69). J. Immunol. 143:1123-1128.

10. Feng, C., et al. 2002. A potential role for CD69 in thymocyte emigration. Int. Immunol. 14:535-544.

11. Nakayama, T., et al. 2002. The generation of mature, single-positive thymocytes in vivo is dysregulated by CD69 blockade or overexpression. J. Immunol. 168:87-94.

12. Lauzurica, P., et al. 2000. Phenotypic and functional characteristics of hematopoietic cell lineages in CD69-deficient mice. Blood. 95:2312-2320.

13. Esplugues, E., et al. 2003. Enhanced antitumor immunity in mice deficient in CD69. J. Exp. Med. 197:1093-1106.

14. Myers, L.K., Rosloniec, E.F., Cremer, M.A., and Kang, A.H. 1997. Collagen-induced arthritis, an animal model of autoimmunity. Life Sci. 61:1861-1878.

15. O'Shea, J.J., Ma, A., and Lipsky, P. 2002. Cytokines and autoimmunity. Nat. Rev. Immunol. 2:37-45.

16. Shull, M.M., et al. 1992. Targeted disruption of the mouse transforming growth factor-beta 1 gene results in multifocal inflammatory disease. Nature. 359:693-699.

17. Kulkarni, A.B., et al. 1993. Transforming growth factor beta 1 null mutation in mice causes excessive inflammatory response and early death. Proc. Natl. Acad. Sci. U. S. A. 90:770-774.

18. Gorelik, L., and Flavell, R.A. 2001. Immune-mediated eradication of tumors through the blockade of transforming growth factor- $\beta$ signaling in T cells. Nat. Med. 7:1118-1122.

19. Letterio, J.J., and Roberts, A.B. 1998. Regulation of immune responses by TGF-beta. Annu. Rev. Immunol. 16:137-161.

20. Kuruvilla, A.P., et al. 1991. Protective effect of transforming growth factor $\beta 1$ on experimental autoimmune disease in mice. Proc. Natl. Acad. Sci. U. S. A. 88:2918-2921.

21. Brandes, M.E., Allen, J.B., Ogawa, Y., and Wahl, S.M. 1991. Transforming growth factor $\beta 1$ suppresses acute and chronic arthritis in experimental animals. J. Clin. Invest. 87:1108-1113.

22. Allen, J.B., et al. 1990. Rapid onset synovial inflammation and hyperplasia induced by transforming growth factor beta. J. Exp. Med. 171:231-247.

23. Prud'homme, G.J., and Piccirillo, C.A. 2000. The inhibitory effects of transforming growth factor-beta-1 (TGF-beta1) in autoimmune diseases. J. Autoimmun. 14:23-42.

24. Campbell, I.K., Hamilton, J.A., and Wicks, I.P. 2000. Collagen-induced arthritis in C57BL/6 (H-2 $\left.{ }^{\mathrm{b}}\right)$ mice: new insights into an important disease model of rheumatoid arthritis. Eur. J. Immunol. 30:1568-1575.

25. Campbell, I.K., et al. 1998. Protection from collagen-induced arthritis in granulocyte-macrophage colony-stimulating factor-deficient mice. J. Immunol. 161:3639-3644.

26. Butler, D.M., et al. 1997. DBA/1 mice expressing the human TNF-alpha 
transgene develop a severe, erosive arthritis: characterization of the cytokine cascade and cellular composition. J. Immunol. 159:2867-2876.

27. Arnett, F.C., et al. 1988. The American Rheumatism Association 1987 revised criteria for the classification of rheumatoid arthritis. Arthritis Rheum. 31:315-324.

28. Dasch, J.R., Pace, D.R., Waegell, W., Inenaga, D., and Ellingsworth, L.R. 1989. Monoclonal antibodies recognizing transforming growth factor beta (TGF- $\beta$ ): bioactivity, neutralization and TGF- $\beta 2$ affinity purification. J. Immunol. 142:1536-1541.

29. Lubberts, E., Joosten, L.A., van de Loo, F.A., van den Gersselaar, L.A., and van den Berg, W.B. 2000. Reduction of interleukin-17-induced inhibition of chondrocyte proteoglycan synthesis in intact murine articular cartilage by interleukin-4. Arthritis Rheum. 43:1300-1306.

30. Sancho, D., et al. 2000. Functional analysis of ligand-binding and signal transduction domains of CD69 and CD23 C-type lectin leukocyte receptors. J. Immunol. 165:3868-3875.

31. Feldmann, M., Brennan, F.M., and Maini, R.N. 1996. Role of cytokines in rheumatoid arthritis. Annu. Rev. Immunol. 14:397-440.

32. Campbell, I.K., O’Donnell, K., Lawlor, K.E., and Wicks, I.P. 2001. Severe inflammatory arthritis and lymphadenopathy in the absence of TNF. J. Clin. Invest. 107:1519-1527.

33. Kehrl, J.H., et al. 1986. Production of transforming growth factor beta by human $\mathrm{T}$ lymphocytes and its potential role in the regulation of $\mathrm{T}$ cell growth. J. Exp. Med. 163:1037-1050.

34. Griffiths, M.M., Encinas, J.A., Remmers, E.F., Kuchroo, V.K., and Wilder, R.L. 1999. Mapping autoimmunity genes. Curr. Opin. Immunol. 11:689-700.

35. Wandstrat, A., and Wakeland, E. 2001. The genetics of complex autoimmune diseases: non-MHC susceptibility genes. Nat. Immunol. 2:802-809.

36. Remmers, E.F., et al. 1996. A genome scan localizes five non-MHC loci controlling collagen-induced arthritis in rats. Nat. Genet. 14:82-85.

37. Mc Indoe, R.A., Bohlman, B., Chi, E., Schuster, E., and Lindhardt, M. 1999. Localization of non-MHC collagen-induced arthritis susceptibility loci in DBA/1j mice. Proc. Natl. Acad. Sci. U. S. A. 96:2210-2214.

38. Lopez-Cabrera, M., et al. 1993. Molecular cloning, expression, and chromosomal localization of the human earliest lymphocyte activation antigen AIM/CD69, a new member of the C-type animal lectin superfamily of signal-transmitting receptors. J. Exp. Med. 178:537-547.

39. Ziegler, S.F., et al. 1993. Molecular characterization of the early activation antigen CD69: a type II membrane glycoprotein related to a family of natural killer cell activation antigens. Eur. J. Immunol. 23:1643-1648.

40. Watson, W.C., and Townes, A. 1985. Genetic susceptibility to murine collagen II autoimmune arthritis. Proposed relationship to the IgG2 autoantibody subclass response, complement C5, major histocompatibility complex (MHC), and non-MHC loci. J. Exp. Med. 162:1878-1891.

41. Feldmann, M. 2002. Development of anti-TNF therapy for rheumatoid arthritis. Nat. Rev. Immunol. 2:364-371.

42. Williams, R.O., Marinova-Mutafchieva, L., Feldmann, M., and Maini, R.N. 2000. Evaluation of TNF- $\alpha$ and IL-1 blockade in collagen-induced arthritis and comparison with combined anti-TNF- $\alpha /$ anti-CD4 therapy. J. Immunol. 165:7240-7245.
43. Ji, H., et al. 2002. Critical roles for interleukin 1 and tumor necrosis factor alpha in antibody-induced arthritis. J. Exp. Med. 196:77-85.

44. Maini, R.N., et al. 1999. Infliximab (chimeric anti-tumour necrosis factor alpha monoclonal antibody) versus placebo in rheumatoid arthritis patients receiving concomitant methotrexate: a randomised phase III trial. ATTRACT Study Group. Lancet. 354:1932-1939.

45. Weinblatt, M.E., et al. 1999. A trial on etanercept, a recombinant tumor necrosis factor receptor: $F c$ fusion protein, in patients with rheumatoid arthritis receiving methotrexate. N. Engl. J. Med. 340:253-259.

46. Hallegua, D.S., and Weisman, M.H. 2002. Potential therapeutic uses of interleukin 1 receptor antagonists in human diseases. Ann. Rheum. Dis. 61:960-967.

47. Chen, Y., Kuchroo, V.K., Inobe, J., Hafler, D.A., and Weiner, H.L. 1994. Regulatory $\mathrm{T}$ cell clones induced by oral tolerance: suppression of autoimmune encephalomyelitis. Science. 265:1237-1240.

48. Powrie, F., Carlino, J., Leach, M.W., Mauze, S., and Coffman, R.L. 1996. A critical role for transforming growth factor-beta but not interleukin 4 in the suppression of T helper type 1-mediated colitis by CD45RB(low) CD4 ${ }^{+}$T cells. J. Exp. Med. 183:2669-2674.

49. Piccirillo, C.A., Chang, Y., and Prud'homme, G.J. 1998. Transforming growth factor beta-1 (TGF- $\beta 1$ ) somatic gene therapy prevents autoimmune disease in NOD mice. J. Immunol. 161:3950-3956.

50. Gorelik, L., and Flavell, R.A. 2000. Abrogation of TGF $\beta$ signaling in T cells leads to spontaneous $\mathrm{T}$ cell differentiation and autoimmune disease. Immunity. 12:171-181.

51. Cazac, B.B., and Roes, J. 2000. TGF- $\beta$ receptor controls B cell responsiveness and induction of IgA in vivo. Immunity. 13:443-451.

52. Walunas, T.L., et al. 1994. CTLA-4 can function as a negative regulator of $\mathrm{T}$ cell activation. Immunity. 1:405-413.

53. Chen, W., Jin, W., and Wahl, S.M. 1998. Engagement of cytotoxic T lymphocyte-associated antigen-4 (CTLA-4) induces transforming growth factor $\beta$ (TGF- $\beta$ ) production by murine $\mathrm{CD}^{+}{ }^{+}$T cells. J. Exp. Med. 188:1849-1857.

54. Santis, A.G., et al. 1992. Tumor necrosis factor-alpha production induced in T lymphocytes through the AIM/CD69 activation pathway. Eur. J. Immunol. 22:1253-1259.

55. McInnes, I.B., Leung, B.P., Sturrock, R.D., Field, M., and Liew, F.Y. 1997. Interleukin-15 mediates $\mathrm{T}$ cell-dependent regulation of tumor necrosis factor-alpha production in rheumatoid arthritis. Nat. Med. 3:189-195.

56. Hernández-García, C., Fernández-Gutiérrez, B., Morado, I.C., Bañares, A.A., and Jover, J.A. 1996. The CD69 activation pathway in rheumatoid arthritis synovial fluid T cells. Arthritis Rheum. 39:1277-1286.

57. Fava, R., Olsen, N., Keski-Oja, J., Moses, H., and Pincus, T. 1989. Active and latent forms of transforming growth factor $\beta$ activity in synovial effusions. J. Exp. Med. 169:291-296.

58. Wahl, S.M., Allen, J.B., Wong, H.L., Dougherty, S.F., and Ellingsworth, L.R. 1990. Antagonistic and agonistic effects of transforming growth factor-beta and IL-1 in rheumatoid synovium. J. Immunol. 145:2514-2519.

59. Yu, X., et al. 2001. Anti-CD69 autoantibodies cross-react with low density lipoprotein receptor-related protein 2 in systemic autoimmune diseases. J. Immunol. 166:1360-1369. 